\title{
Further Thoughts on E18 Saltfleetby
}

\author{
Judith Jesch (University of Nottingham)
}

\begin{abstract}
The article reconsiders some of the runological, linguistic and cultural aspects of the 2010 find in Lincolnshire, England, of a lead spindle whorl inscribed with Scandinavian runes. In particular, the discussion leads to the conclusion that the inscription, which appears to mention the god-names Óðinn and Heimdallr, may be somewhat later than previously thought (late eleventh or even twelfth century) and that it does not necessarily provide evidence for heathen beliefs in Lincolnshire at the time.
\end{abstract}

Keywords: Lead spindle whorl, Scandinavian runes, Lincolnshire, Old Norse god-names

\section{The inscription}

F ound in 2010 by a metal detectorist, the rune-inscribed lead spindle whorl from Saltfleetby St Clements, Lincolnshire, in the east of England, has been ably presented by John Hines in numerous seminars and lectures and now in a recent article (Hines 2017). The object is in private ownership and Hines's observations are particularly valuable as he is one of the few runologists who has examined it in person. The inscription has been designated E 18 (no. 18 from England) in the Scandinavian Runic Text Database (Samnordisk runtextdatabas), following the numbering system in Barnes and Page 2006. The aim of this paper is to stimulate the discussion of some aspects of the inscription in more detail and, in particular, to reconsider Hines's assertion that it provides "a glimpse of the heathen Norse in Lincolnshire".

Jesch, Judith. "Further Thoughts on E18 Saltfleetby."

Futhark: International fournal of Runic Studies 9-10 (2018-2019): 201-213.

DOI: $10.33063 /$ diva-401054 
Hines gives a detailed description of the spindle whorl and provides (pp. $119 \mathrm{f} ., 122)$ the following transliteration, normalisation and translation of the inscription:

$\times$ open . ok . einmtalr . ok : palfa . peir

(.) ielba . peruolflt . ok . kiriuesf

Óđinn ok Heimdallr ok Palfa, peir hjálpa pér Ulfljót ok ...

Óðinn and Heimdallr and Palfa, they are helping you, Úlfljót, and ...

Hines does not provide a transrunification, though he does provide (p. 120) his own drawing of the inscription and also comments on some, though not all, of the rune forms. There are some excellent photographs on the Portable Antiquities Scheme website (PAS ID LIN-D92A22), allowing some of the details of the object to be presented in a way that will further runological and historical discussion.

Based on these photographs, and with the proviso that personal examination might suggest different readings, the following transrunification and transliteration are proposed (with the English translation left for the moment as proposed by Hines):

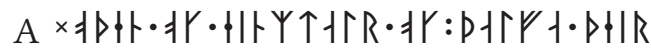

$$
\begin{aligned}
& \begin{array}{lllll}
5 & 10 & 15 & 20 & 25
\end{array}
\end{aligned}
$$

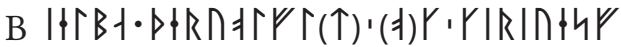

$$
\begin{aligned}
& \begin{array}{llll}
30 & 35 & 40 & 45
\end{array} \\
& \text { A } \quad \text { open } \cdot \text { ok } \cdot \text { einmtalr } \cdot \text { ok : palfa } \cdot \text { peir } \\
& \text { B ielba · peruolfl(t) , (o)k , kiriuesf }
\end{aligned}
$$

Line A of the inscription is cut around the wall of the spindle whorl, while Line $B$ is on the flat face, which would normally face upwards when in use. Runes 39 and 40 are presented here as uncertain because the photographs make it difficult to assess the presence of possible branches (fig. 1). Runes 12 and 18, that Hines transliterates as $\mathbf{a}$ in einmtalr and in the first vowel of palfa, are presented in his drawing as the fourth rune $\neq$ (which he otherwise transliterates as $\mathbf{0}$ ) - this is presumably an error, since his transliterations in these instances are correct even though the drawing is not. Other differences between the transrunification proposed above and Hines's drawing are a matter of judgement, such as whether these and other $a$-runes are long-branch or short-twig when the branch crosses the stave 


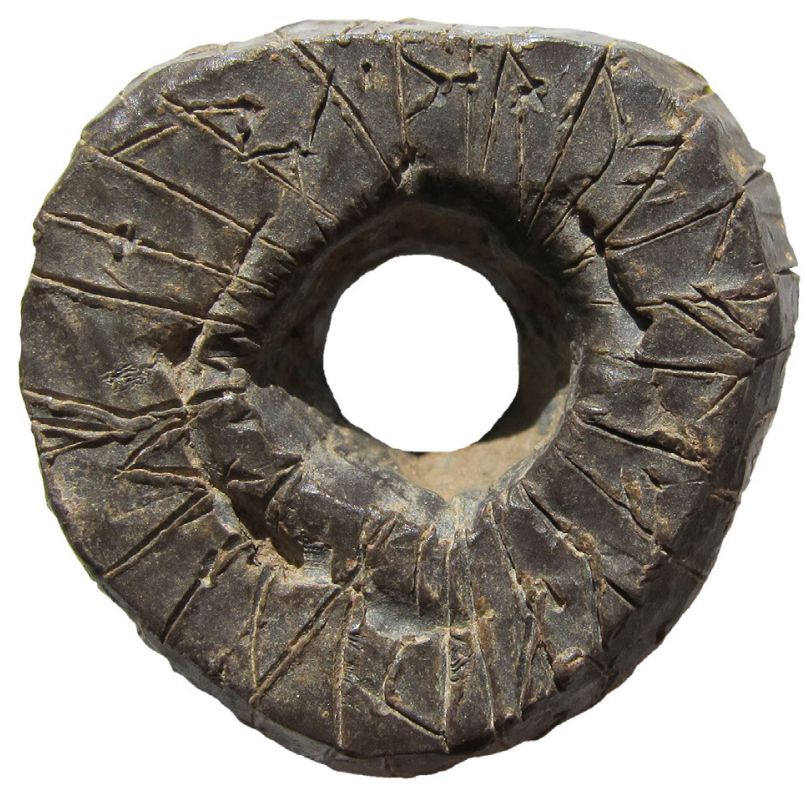

Fig. 1. Line B of the Saltfleetby spindle-whorl inscription. Rights holder: Lincolnshire County Council (CC BY-SA).

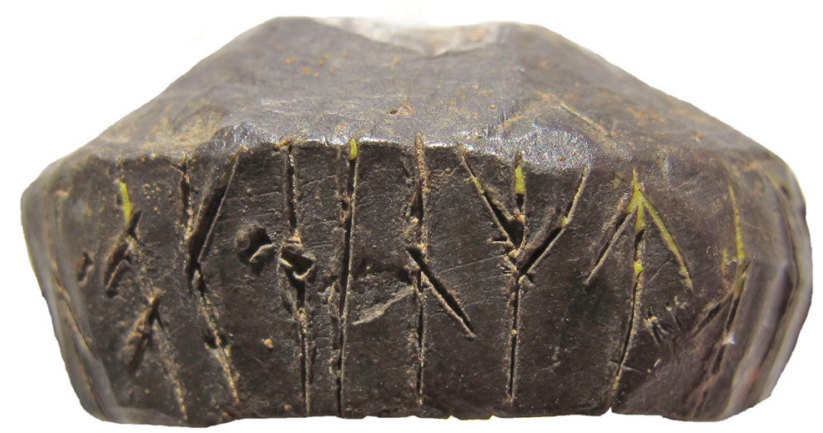

Fig. 2. The Saltfleetby spindle-whorl inscription showing runes 5-13: • ok • einmtal. Rights holder Lincolnshire County Council (CC BY-SA).

only slightly. It is my judgement that the $a$ - and $n$-runes in this inscription are intended to be one-sided (contra Hines 2017, 119; see e.g. figs 1 and 2). I would also suggest that Hines makes too much of the "Danish" (i.e. longbranch) character of the inscription, disregarding the cogent arguments made by Michael Barnes (2006, 20-22) for an "alphabet continuum" which 
recognises the diversity of rune forms found in actual inscriptions, rather than a rigid adherence to the concepts of "long-branch" and "short-twig" derived from modern standardised futharks. This approach may have consequences for understanding the inscription, as discussed below.

\section{Interpretation}

The most striking part of the inscription as read by Hines is the first word, which he interprets as the god-name Oðinn. A genuine runic reference to this heathen god in the Viking Age, anywhere, let alone in England, with its few inscriptions and general lack of evidence for the Norse gods (Jesch 2011), does indeed "create astonishment" (Hines 2017, 125). It is perhaps equally astonishing if the second word does represent the god-name Heimdallr, as this name does not to my knowledge occur in any runic inscription (on the god more generally, see Cöllen 2015). Thus it is important to understand the Saltfleetby inscription as best we can, not least in view of the interest it has sparked among non-runologists, both academic and in the general public. Hines's analysis and overall interpretation of the inscription are in general perfectly reasonable and quite cautious, and he recognises that some parts of it must remain uninterpretable for the time being. However, his conclusion that the inscription provides "evidence for a genuine ritual adherence to the pre-Christian deities" (Hines 2017, 125) is open to question. He arrives at this conclusion despite drawing attention to a complicating chronological paradox: "Archaeologically, it would be very surprising if the Saltfleetby inscription had been made as late as the post-Conquest period [i.e. after 1066] ... although both runographically and philologically that would be a very comfortable dating". This object itself is a spindle whorl of type A1, which could date from $600-1000$, but perhaps most likely from the tenth century (Hines 2017, 122). ${ }^{1}$ Apparently, therefore, we have an eleventh-century inscription on a tenth-century object, although Hines passes rather lightly over the possibility that the inscription could have been added later to a pre-existing object. There is no shortage of runic inscriptions made on objects of an earlier date, however a dating of the inscription to the eleventh century "at the earliest" would make Hines's argument $(2017,125)$ of "genuine ritual adherence to the pre-Christian deities” quite problematic.

\footnotetext{
${ }^{1}$ Hines does not discuss the curved lines on the conical part of the spindle whorl. Whether these are ornamental or have some other significance, and whether they are contemporaneous with the runes are questions that deserve further investigation.
} 


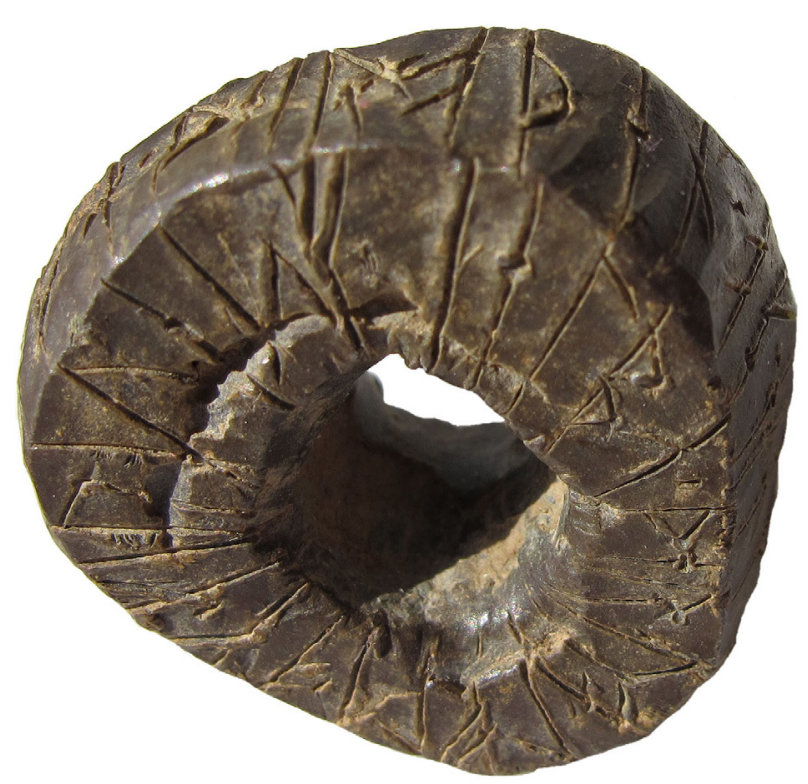

Fig. 3. The Saltfleetby spindle-whorl inscription, showing the words open and ielba. Rights holder Lincolnshire County Council (CC BY-SA).

We do not know when the Scandinavian settlers of Lincolnshire converted to Christianity, and no doubt the process was not even across this large county, but most historians would be surprised to find evidence of genuine paganism there in the eleventh century, let alone any later (Abrams 2000, 2014, Barrow 2000). Hines addresses this by proposing $(2017,125)$ that "the object and its inscription may represent individuality and non-conformity ... rather than a hitherto unsuspected, general cultural cleft in that context". However, the runological evidence considered below suggests that a better explanation would involve a later dating of the inscription, perhaps as late as the twelfth century, and an acceptance that a mention of Óðinn is not necessarily evidence for "genuine ritual adherence" to heathen deities. ${ }^{2}$

\footnotetext{
${ }^{2}$ A similar question arises in connection with the Nordendorf I fibula (KJ 151) with an inscription in the older futhark. Dating to the sixth century, and from a female grave in southern Germany, this inscription also contains the south Germanic equivalent of Óðinn, namely wodan, and probably one, and possibly two, more god-name(s). Interpretations of this inscription vary between seeing it as evidence for heathen belief or for the renunciation of the old gods by a new Christian (Düwel 1992, 356-59).
} 
Starting with that all-important first word, Hines notes (2017, 119) that open is "a known runic spelling of the name of the god" (fig. 3). What he does not mention is that the two instances of this runic spelling which indubitably refer to the god occur in medieval inscriptions from Bergen in Norway, one dated to the twelfth and one to the fourteenth century (discussed below). ${ }^{3}$ Hines does discuss the eighth-century skull from Ribe (DR EM85;151B; Søvsø 2013) which has the third indubitable runic reference to Óðinn, but does not mention that it spells the name as upin, as indeed would be expected in the early Viking Age. ${ }^{4}$ Before turning to the two medieval Norwegian inscriptions, it is worth pausing to consider this and other relevant spellings. Other than on the Ribe skull, the name Óðinn does not occur as a simplex in any runic inscriptions from the Viking Age. It may however occur as the first element in two personal names, m. Óðinkárr which occurs in four Danish inscriptions, always spelled upinkaur (DR 4, DR 81, DR 133, DR 239) and f. Óðindísa spelled opintisu in an oblique case on Vs 24. The former name also occurs in a medieval inscription from Norway where it is spelled opinkar (N 3). ${ }^{5}$

In relation to this orthography it is worth noting the spelling of the personal name Loðinn. Although its first vowel, unlike that of Óðinn, is short, it follows the same pattern in that this vowel is generally represented by $\mathbf{u}$ in Viking Age inscriptions, i.e. Iupin (possibly Sö 16, more certainly U 347, U 592, U 831, N 431), though once lopin (U 405), and always o in medieval inscriptions (lopin N B334 or loden N 69). Also with $\mathbf{0}$, but additionally with a lowered vowel in the unstressed syllable (like Saltfleetby) are three other medieval instances of this name: lopen in N 70, lopenn N 497, and lopæn in DR 92. Here we might also compare the past participle stroðinn spelled stropen in N A322. From these forms we would expect the most likely medieval spelling of Óðinn to be open and that is indeed what we find in the two Norwegian examples already mentioned, twice in N B241 (the first time using a bind-rune open) dated 1375-1400 and once in N B380 dated c. 1185 (both dates are archaeological datings as recorded in the Scandinavian Runic Text Database and may need revision

\footnotetext{
${ }^{3}$ Runic inscriptions discussed in this paper are referred to, where available, by the signum identifier in the Scandinavian Runic Text Database. Where statements are made about the number of examples of a particular spelling, for example, these are based on searches conducted in the Scandinavian Runic Text Database.

${ }^{4}$ I follow runological practice in using 'Viking Age' to refer to inscriptions from before c. $1050 / 1100$ and 'medieval' for those dated to later than that.

${ }^{5}$ On whether the first element in these names is actually the same as the god-name, see the brief discussion with references in Insley 1994, 85 note 187.
} 
in the light of further research). Furthermore, óðinsdaginn 'Wednesday' is spelled opesndhen in the fourteenth-century N 179. Overall, the use of $\mathbf{0}$ for the stressed vowel is more likely to be medieval, though Vs 24 and U 405 suggest that a (late?) Viking Age date cannot be completely ruled out.

Hines $(2017,120)$ notes that "The $\mathbf{e}$ in the second, unstressed syllable in open can be explained in terms of regular sound-change either as the 'harmonisation' of the unstressed vowel to the middle back vowel [o:] in the first syllable or as reduction of [i] to [ə] under low stress" (referring to Seip 1955, 128, 132-37). However, he does not comment on the chronology of these sound changes, nor indeed on the fact that he is using Norwegian sound changes to explain an inscription he sees as most likely Danish (Hines 2017, 123). Seip $(1955,128)$ dates the first of these options (vowel harmony) to the twelfth century, but it is of course a phenomenon found in certain dialects of Norway and not across the Viking world, and in any case its age is uncertain. The second option, the reduction of the vowel in a position of low stress, is also dated to the twelfth century (Seip $1955,132)$ in a Norwegian context, but again more in some dialects than others. In runic inscriptions, Viking Age examples of -inn spelled as -en seem to be restricted to the reflexive possessive sinn (many examples). In unstressed syllables (mainly the suffixed definite article, or the suffix in dróttinn), there are many runic examples, mostly from Norway, but all are medieval (DR 169, N 170, N 179, N 291, N 309, N 319, N 393, N 606, N A49, N A208, N A322). On this evidence, open in the Saltfleetby inscription is looking more like a post-Viking Age form than one from the Viking Age, even the late Viking Age, and appears also to fit comfortably in a Norwegian context.

At this point it is worth a brief detour to note that the name Óðinn does occur in Viking Age sources from England, in texts written by Englishmen that nevertheless reveal their knowledge of Norse linguistic forms. The tenth-century chronicler Æthelweard, writing in Latin, used what Townend $(2002,122)$ has called a "compromise form arising from the coexistence of competing English and Norse forms of the same name", namely Vuothen in which "initial OE $w$ is preserved, but medial ON $\partial$ introduced in place of $\mathrm{OE} d$." Although Townend does not comment on the vowel of the second syllable, he seems to think it represents the same vowel as in Old English Wōden. While it is conceivable that Saltfleetby contains some similarly hybrid form, it seems unlikely that such a hybrid would show loss of the initial consonant in the stressed syllable while retaining the vowel of the unstressed second syllable. The late tenth- and early eleventh-century homilists Ælfric and Wulfstan both refer to Óðon or 
Oðon in their Old English homilies De falsis diis, specifying that this name is in the Danish language (Townend 2002, $129 \mathrm{f}$., $138 \mathrm{f}$.). A further tenthcentury document (the Latin Historia de Sancto Cuthberto) has the form Othan (Townend 2002, $141 \mathrm{f}$.). These forms, if indeed they do represent Scandinavian speech, all lack the initial Old English $w$, and seem to confirm that the Saltfleetby form is not that of an English speaker. More like the Saltfleetby inscription is the earliest recorded spelling of the North Yorkshire place-name Roseberry Topping, which is Othenesberg in 1119 (Smith 1928, 164; the process by which the current name is derived is explained in Rye 2014, 21 f.), as also noted by Hines $(2017,124)$. This is in a region with extensive Scandinavian settlement as suggested by the place-names, and it is likely that this spelling reflects the local pronunciation at the time. Somewhat earlier, Domesday Book for Lincolnshire records in 1086 a number of people called Odincar or Odincarl(e), with medial $\partial$ represented by $d$ as is common in that text (Fellows Jensen 1968, xcii f., 203 f.). ${ }^{6}$

In an English context, however, the spelling open could also represent a different name entirely, namely Auðun, frequent in Old West Norse (Lind 1915, cols 102-06). In his discussion of this name, John Insley (1994, 84-86) notes that it "is fairly frequent in English sources" despite being rare in Old Danish and Old Swedish, where it is generally late medieval (though see some probable Viking Age examples in Peterson 2007, 36), and posits an Anglo-Scandinavian form Ōðin. The possibility that Saltfleetby represents this name should not be excluded and a Norfolk fieldname spelled Odenhou in the thirteenth century cited by Insley may be a relevant parallel (see also Rye 2013, 21, on this name as a possible etymon for Othenesberg/Roseberry Topping).

Also relevant to the dating of the Saltfleetby inscription is Hines's comment $(2017,120 \mathrm{f}$.) that the masculine nominative singular ending of einmtalr is expressed by the fifth rune $\mathbf{r}$ rather than the sixteenth rune $\mathbf{R}$ and the fact that this usage is "common in later Viking-period inscriptions". He seems to base this comment on his already-noted assumption that the inscription is in long-branch runes and therefore most likely to be of Danish origin. The phoneme $/ \mathrm{R} /$ coalesced with $/ \mathrm{r} /$ much earlier in western Scandinavia than in the east and the product was represented by $\mathbf{r}$, not $\mathbf{R}$ (Larsson 2002, 132). This word, if it does indeed represent the god-name

\footnotetext{
${ }^{6}$ There is perhaps additional evidence for the knowledge of Oððinn in Viking Age Lincolnshire in the form of the Winteringham pendant, another metal detectorist find apparently showing a one-eyed figure with two birds on its shoulders (PAS ID NLM-7F954A). Winteringham is some $85 \mathrm{~km}$ north-west of Saltfleetby, on the south bank of the Humber.
} 
Heimdallr, could as well be a medieval Norwegian spelling: compare alr for the adjective allr in $\mathrm{N} 122$ and halr for the personal name Hallr in N A138 dated to 1225-75 and also in N A296 where it represents the noun or adjective hallr.

Finally, Hines points to the spelling of hjálpa as ielba (fig. 3) and asserts $(2017,121)$ that Saltfleetby "provides unusually, but not implausibly, early evidence" for the raising of "the erstwhile -ja-diphthong" as in the modern Scandinavian languages. How unusual the spelling is does depend on the date of Salfleetby. The verb hjálpa is very common in runic inscriptions and although forms with hialb- are predominant, there is a wide variety of spellings and both the loss of $h$ and various representations of the rising diphthong can be found. Spellings in -ie- are common in Viking Age inscriptions, with at least fourteen reasonably certain examples (Ög 239, U 2, U 38, U 650, U 690, U 722, U 808, U 813, U 815, U 819, U 873, G 134, G 203, G 279). Similar are at least thirty-one reasonably certain examples with -ei-, -e- and, most frequently, -i- (Öl 4, Ög 228, Sö 14, Sö 19, Sö 125, Sö 174, Sö 181, Sö 212, Sö 255, Sö 347, U 108, U 126, U 160, U 319, U 323, U 338, U 341, U 518, U 645, U 681, U 691, U 696, U 758, U 759, U 857, U 954, U 1067, U 1155, Vs 5, G 276, DR 345) and five examples spelled ihlbi (U 319 , $\mathrm{U} 323, \mathrm{U} 338, \mathrm{U} 518, \mathrm{U} 681$ ). While this progressive $j$-mutation is not well documented in Norwegian inscriptions, it does appear in manuscripts from the early 1200s onwards (Hagland 2013, 622). Thus, the particular form of Saltfleetby (i.e. ielba) is inconclusive regarding the date of the inscription. If Viking Age, it may suggest a carver using East Norse forms, in contrast to the other spellings discussed above, but if later, it would, like the other spellings, conform to a later, possibly more West Norse form of the language. It is worth noting that, in runic usage, the subject of the verb 'to help' is almost universally a Christian deity, figure or abstraction. An exception is the aforementioned Ribe skull, the exact interpretation of which is uncertain, but in which there seems to be a connection between the runic sequence Hialb, whether noun or verb, and the three names preceding it, one of which is Oðinn, as already mentioned. Overall, the evidence suggests a later date rather than an earlier one, most likely medieval rather than Viking Age.

\section{Discussion}

Since we have relatively little comparative material, we cannot rule out either a Scandinavian speaker from Lincolnshire or a visiting Scandinavian 
as the carver of the inscription, though given the very local nature of the object (Hines 2017, 122), any such person carving in Norway or Denmark must be less likely. As to whether this person was pagan or Christian, we cannot know for certain, though it is worth noting that the two Norwegian inscriptions which mention O̊đinn are from well within the Christian period. Explicitly Christian is N B241 (a six-sided rune stick dated to the last quarter of the fourteenth century), in which Ódinn is called upon to reveal the name of a thief fyr kristni 'for (the sake of) Christianity' and concludes with (a conjectural) Amen. N B380 (a rune stick dated to ca. 1185) is closer in date to Saltfleetby and is a simple invocation to the two best-known gods:

hæil : se pu : ok : i huhum : gopom | por : pik : pig:gi : open : pik : æihi :

Heil(l) sé pú ok í hugum góðum. Pórr pik piggi, Óðinn pik eigi.

May you be healthy and in good spirits. ${ }^{7}$ May Pórr receive you, may Óðinn own you.

This seems very close in spirit and function to the Saltfleetby inscription.

There is evidence that Scandinavians in England did not shy away from referring to their heathen gods in certain contexts even when they were Christians (Jesch 2001, 319 f.; 2004; Abrams 2014, 337). Both Óðinn and Heimdallr are thought to be depicted on Viking Age but Christian sculptured monuments from northern England and the Isle of Man (as argued by Kopár 2012, 12, 64, 72, 79, 91 f., 103, 110-23, and Wilson 2018, 106-09; Cöllen 2015, $173 \mathrm{f}$. is more skeptical about depictions of Heimdallr). Moreover, much Old Norse literature shows that the Icelanders and Norwegians did not forget the old deities for a long time after their conversion. Both these parallels and the runic evidence suggest that the Saltfleetby inscription could easily have been carved by a Scandinavian-speaking Christian resident of either Lincolnshire or Norway in the twelfth century (with Denmark possible but less likely). That there were contacts between these two regions we know from the career of Earl Rognvaldr of Orkney, who knew and used runes, and sailed from Bergen to Grimsby, less than 30 kilometres north of Saltfleetby, in the 1140s, and who also referred to Old Norse mythology in his poetry (Jesch 2015, 147-50). Slightly later, perhaps around the year 1200, the undoubtedly Christian bishop of Orkney Bjarni Kolbeinsson specifically invokes Óđinn in his skaldic poem fómsvíkingadrápa (Jesch 2015, 148). But probably the direct connection with Norway

${ }^{7}$ The translation in the Scandinavian Runic Text Database 'Hail to you and good thoughts' is incorrect.

Futhark 9-10 (2018-2019) 
is the most relevant: Norwegian merchants were frequent enough in Grimsby in the third quarter of the twelfth century for King Henry II to issue a writ enforcing the right of the reeves of Lincoln to take tolls from them (Douglas and Greenaway 1981, 1039 f.).

Even if this suggested redating of its inscription to the twelfth century is correct, the Saltfleetby spindle whorl remains mysterious. If this dating is incompatible with the archaeological dating of the object, do we have a later inscription added to an earlier object, or should we ask the archaeologists to revisit the dating of the object? In this matter I am not competent to judge, but regardless of its date, other questions suggest themselves. Why is there apparently an invocation to Heimdallr, a god not otherwise invoked in runic inscriptions? Who or what is Palfa? Can any sense be made of the last eight runes? There is certainly still much food for further thought. Until further elucidations, I hope at least to have shown that we should not automatically assume that the mention of a Norse god in a runic inscription is necessarily evidence for heathen belief and custom, and that such mentions could happen well after the official conversion to Christianity, even in the Viking diaspora.

\section{Bibliography}

Abrams, Lesley. 2000. "Conversion and assimilation." In Cultures in Contact: Scandinavian settlement in England in the ninth and tenth centuries, ed. Dawn M. Hadley and Julian D. Richards, 135-53. Studies in the Early Middle Ages, 2. Turnhout.

—. 2014. "The conversion of Scandinavians in Britain and Ireland: An overview." In Vers l'Orient et vers l'Occident: Regards croisés sur les dynamiques et les transferts culturels des Vikings à la Rous ancienne, ed. Pierre Bauduin and Alexander E. Musin, 327-37. Caen.

Barnes, Michael. 2006. "Standardised fuparks: A useful tool or a delusion?" In Runes and their Secrets: Studies in runology, ed. Marie Stoklund, Michael Lerche Nielsen, Bente Holmberg and Gillian Fellows-Jensen, 11-29. Copenhagen.

Barnes, Michael P., and R. I. Page. 2006. The Scandinavian Runic Inscriptions of Britain. Runrön, 19. Uppsala.

Barrow, Julia. 2000. "Survival and mutation: Ecclesiastical insitutions in the Danelaw in the ninth and tenth centuries." In Cultures in Contact: Scandinavian settlement in England in the ninth and tenth centuries, ed. Dawn M. Hadley and Julian D. Richards, 155-76. Studies in the Early Middle Ages, 2. Turnhout.

Cöllen, Sebastian. 2015. Heimdallr-der rätselhafte Gott. Ergänzungsbände zum Reallexikon der Germanischen Altertumskunde, 94. Berlin.

Douglas, David C., and George W. Greenaway. 1981. English Historical Documents 1042-1189. 2nd ed. London. 
$\mathrm{DR}+$ number $=$ inscription published in Danmarks runeindskrifter, by Lis Jacobsen and Erik Moltke, 3 vols: Text; Atlas; Registre (København, 1941-42).

DR EM85;151B = inscription from Ribe, Nørreylland. Published on p. 151 in Erik Moltke, Runes and their Origin, Denmark and Elsewhere (Copenhagen, 1985).

Düwel, Klaus. 1992. "Runeninschriften als Quellen der germanischen Religionsgeschichte." In Germanische Religionsgeschichte: Quellen und Quellenprobleme, ed. Heinrich Beck, Detlev Ellmers and Kurt Schier, 336-64. Ergänzungsbände zum Reallexikon der germanischen Altertumskunde, 5. Berlin.

$\mathrm{E}+$ number = inscription from England, either unpublished or published in Barnes and Page 2006.

Fellows Jensen, Gillian. 1968. Scandinavian Personal Names in Lincolnshire and Yorkshire. Copenhagen.

$\mathrm{G}+$ number = inscription published in Gotlands runinskrifter, by Sven B. F. Jansson, Elias Wessén and Elisabeth Svärdström = Sveriges runinskrifter, vols 11-12, publ. Kungl. Vitterhets Historie och Antikvitets Akademien (Stockholm, 196278). For numbers above G 222 see Helmer Gustavson and Thorgunn Snædal, manuscript of Gotlands runinskrifter, part 3, at http://www.raa.se/kulturarvet/ arkeologi-fornlamningar-och-fynd/runstenar/digitala-sveriges-runinskrifter/ gotlands-runinskrifter-3/ under "Supplement till Gotlands runinskrifter del 1 och 2".

Hagland, Jan Ragnar. 2013. "Gammalislandsk og gammalnorsk språk.” In Handbok i norrøn filologi, ed. Odd Einar Haugen, 600-38. 2nd ed. Bergen.

Hines, John. 2017. "A glimpse of the heathen Norse in Lincolnshire." In Crossing Boundaries: Interdisciplinary approaches to the art, material culture, language and literature of the early medieval world, ed. Eric Cambridge and Jane Hawkes, 118-26. Oxford.

Insley, John. 1994. Scandinavian Personal Names in Norfolk: A survey based on medieval records and place-names. Acta Academiae Regiae Gustavi Adolphi, 62. Uppsala.

Jesch, Judith. 2001. "Skaldic verse in Scandinavian England." In Vikings and the Danelaw, ed. James Graham-Campbell, Richard Hall, Judith Jesch and David Parsons, 313-25. Oxford.

— . 2004. "Scandinavians and 'cultural paganism' in late Anglo-Saxon England." In The Christian Tradition in Anglo-Saxon England: Approaches to current scholarship and teaching, ed. Paul Cavill, 55-68. Cambridge.

— . 2011. "The Norse gods in England and the Isle of Man." In Myths, Legends, and Heroes: Essays on Old Norse and Old English Literature, ed. Daniel Anlezark, 11-24. Toronto.

- 2015. The Viking Diaspora. London.

$\mathrm{KJ}+$ number $=$ inscription published in Die Runeninschriften in älteren Futhark, by Wolfgang Krause and Herbert Jankuhn, Abhandlungen der Akademie der Wissenschaften in Göttingen, Philologisch-Historische Klasse, 3rd ser., 66 (Göttingen, 1966). 
Kopár, Lilla. 2012. Gods and Settlers: The iconography of Norse mythology in AngloScandinavian sculpture. Turnhout.

Larsson, Patrik. 2002. Yrrunan: Användning och ljudvärde i nordiska runinskrifter. Runrön, 17. Uppsala.

Lind, E. H. 1915. Norsk-isländska dopnamn ock fingerade namn från medeltiden. Uppsala.

$\mathrm{N}+$ number $=$ inscription published in Norges innskrifter med de yngre runer, by Magnus Olsen et al., 6 vols. to date (Oslo, 1941-).

$\mathrm{N} \mathrm{A}+$ number $=$ preliminary registration number in the Oslo Runic Archives of runic inscriptions found in Norway outside Bryggen in Bergen.

$\mathrm{N} \mathrm{B}+$ number $=$ preliminary registration number in the Oslo Runic Archives of runic inscriptions found at Bryggen in Bergen.

Òg + number = inscription published in Óstergötlands runinskrifter, by Erik Brate = Sveriges runinskrifter, vol. 2, publ. Kungl. Vitterhets Historie och Antikvitets Akademien (Stockholm, 1911-18).

PAS = Portable Antiquities Scheme. https://finds.org.uk

Peterson, Lena. 2007. Nordiskt runnamnslexikon. Uppsala.

Rye, Eleanor. 2014. "Scandinavian place-names in Cleveland." In The Vikings in Cleveland, ed. Heather O’Donoghue and Pragya Vohra, 21-25, Nottingham. [also at https://languagesmythsfinds.files.wordpress.com/2013/09/lmf4.pdf]

Scandinavian Runic Text Database, Department of Scandinavian Languages, Uppsala University (Samnordisk runtextdatabas, Institutionen för nordiska språk, Uppsala universitet). http://www.nordiska.uu.se/forskn/samnord.htm

Seip, Didrik Arup. 1955. Norsk språkhistorie til omkring 1370. 2nd ed. Oslo.

Smith, A[lbert]. H[ugh]. 1928. The Place-Names of the North Riding of Yorkshire. Cambridge.

Sö + number $=$ inscription published in Södermanlands runinskrifter, by Erik Brate and Elias Wessén = Sveriges runinskrifter, vol. 3, publ. Kungl. Vitterhets Historie och Antikvitets Akademien (Stockholm, 1924-36).

Søvsø, Morten. 2013. "Om dateringen af Ribe runehjerneskallen.” Futhark 4: 17376.

Townend, Matthew. 2002. Language and History in Viking Age England: Linguistic relations between speakers of Old Norse and Old English. Studies in the Early Middle Ages, 6. Turnhout.

$\mathrm{U}+$ number = inscription published in Upplands runinskrifter, by Elias Wessén and Sven B. F. Jansson = Sveriges runinskrifter, vols 6-9, publ. Kungl. Vitterhets Historie och Antikvitets Akademien (Stockholm, 1940-58).

Vs + number $=$ inscription published in Västmanlands runinskrifter, by Sven B. F. Jansson = Sveriges runinskrifter, vol. 13, publ. Kungl. Vitterhets Historie och Antikvitets Akademien (Stockholm, 1964).

Wilson, David M. 2018. Manx Crosses: A handbook of stone sculpture 500-1040 in the Isle of Man. Oxford. 
